(C) 2014

\author{
Пелих В. Г., доктор сільськогосподарських наук, професор, илен-кореспондент НААНУ, \\ Чернишов І. В., кандидат сільськогосподарських наук \\ ДВНЗ Херсонський ДАУ
}

\title{
ВПЛИВ ПАРАМЕТРІВ КОНСОЛІДАЦІЇ ГРУП ЗА ЖИВОЮ МАСОЮ ТА РІВНОМІРНІСТЮ РОСТУ НА ДИНАМІКУ РОСТУ МОЛОДНЯКУ СВИНЕЙ
}

\author{
Рецензент - доктор сільськогосподарських наук, професор Б. О. Вовченко
}

У статті показано вплив вирівняності груп свиней за живою масою на час відлучення від свиноматки й параметра рівномірності росту в підсисний період на продуктивні якості свиней. Доведено суттєвий вплив зазначених параметрів на динаміку средньодобових і відносних приростів та мінливість живої маси свиней. Отримані дані доцільно використовувати на племінних заводах, племрепродукторах $і$ товарних фермах для оптимальної комплектації груп свиней, підвищення енертї їх росту на вирощуванні й відгодівлі та отримання однорідної продукиії.

Ключові слова: індекс вирівняності гнізд, параметри росту, молодняк свиней, велика біла порода.

Постановка проблеми. Підвищення продуктивних якостей сільськогосподарських тварин у значній мірі обумовлено розробкою теоретичних і практичних питань, спрямованих на вивчення закономірностей їх індивідуального розвитку. Показники живої маси й параметри росту - важливі критерії в оцінці продуктивності свиней $[1,2]$.

У процесі розвитку і росту тварин необхідно створювати такі умови, які б найповніше сприяли прояву породних й індивідуальних особливостей, формуванню високої продуктивності, міцності кістяка та пристосування до тривалого інтенсивного племінного використання, поскільки ріст i розвиток тварин відбувається шляхом складної взаємодії спадкової основи організму 3 конкретними умовами зовнішнього середовища й $є$ важливим фоном для реалізації генетичного потенціалу продуктивності тварин.

Аналіз основних досліджень і публікацій, у яких започатковано розв'язання проблеми. Відомо, що успішне вирощування поросят (особливо з низькою живою масою на час народження) значно залежить від створення оптимальних умов для них у процесі вирощування. Численними дослідженнями встановлено, що в значній мірі ефективність вирощування поросят можна підвищити за рахунок формування груп у різні періоди з урахуванням живої маси, проте комплексне вивчення впливу вирівняності груп свиней і рівномірності їх росту на показники живої маси залишається актуа- льним, чим і обумовлена дана стаття $[3,4]$.

Мета і завдання досліджень. Метою досліджень було вивчення впливу онтогенетичних факторів на продуктивні якості свиней; дослідження особливостей росту ремонтного молодняку залежно від їх походження з вирівняних i невирівняних гнізд та рівномірності росту в підсисний період.

Завданням досліджень було вивчення впливу вирівняності груп свиней за живою масою та параметру рівномірності росту в підсисний період на продуктивні якості свиней.

Матеріали і методи досліджень. Експериментальні дослідження проведені в умовах ВАТ «Племзавод Степной» Кам'янсько-Дніпровського району Запорізької області.

Об'єктом досліджень служили ремонтні свинки великої білої породи. 3 метою вивчення росту та розвитку молодняку було сформовано 4 групи свиней за методом планування експериментів $2^{2}$, де використовувалися два однакові за вирівняністю гнізд на час відлучення свиноматки (нижче середнього значення $\mathrm{M}^{-}$, вище середнього значення $\mathrm{M}^{+}$) $\mathrm{i}$ два рівні за рівномірністю росту у підсисний період (нерівномірні - нижче середнього значення, рівномірні - вище середнього) $[1,2,5]$.

Результати досліджень. Оцінка свинок великої білої породи за живою масою протягом досліджуваного періоду свідчить про наявність певних відмінностей між тваринами (табл. 1).

Встановлено, що тварини різних піддослідних груп росли з неоднаковою інтенсивністю. У віковий період 2-4 місяці свинки класу « $\mathrm{M}+\times$ рівномірні» збільшили свою живу масу на 24,44 кг, а класу «М- × нерівномірні» - на 19,27 кілограма. У наступному віковому періоді (4-6 місяців) тварини класу «М+ × рівномірні» дали приріст живої маси 27,75 кілограма. $\mathrm{У}$ той же час свинки класу «M- $\times$ нерівномірні» поступалися їм за цим показником на 7,75 кг, класу « $\mathrm{M}+\times$ нерівномірні» - на 1,82 кг. У цілому за 4-місячний період жива маса свинок « $\mathrm{M}+\times$ рівномірні» підвищилася на 52,19 кг, а маса свинок «М- × нерівномірні» - на 39,27 кілограма. 
СІЛЬСЬКЕ ГОСПОДАРСТВО. ТВАРИННИЦТВО

1. Динаміка живої маси піддослідних тварин

\begin{tabular}{|c|c|c|c|c|c|}
\hline \multicolumn{2}{|c|}{ Клас розподілу за } & \multirow[b]{2}{*}{$\begin{array}{l}\mathrm{n}, \\
\text { голів }\end{array}$} & \multicolumn{3}{|c|}{ Жива маса (кг) у віці (місяців) } \\
\hline $\begin{array}{c}\text { вирівняністю } \\
\text { гнізда на час } \\
\text { відлучення } \\
\text { свиноматки } \\
\text { (у } 45 \text { діб) }\end{array}$ & $\begin{array}{l}\text { рівномірністю } \\
\text { росту }\end{array}$ & & 2 & 4 & 6 \\
\hline \multirow{2}{*}{$\mathrm{M}^{-}$} & нерівномірні & 16 & $13,64 \pm 0,34^{* * *}$ & $32,93 \pm 0,55^{* * *}$ & $56,93 \pm 1,22^{* * *}$ \\
\hline & рівномірні & 17 & $14,40 \pm 0,27^{* *}$ & $34,40 \pm 0,60^{* *}$ & $59,70 \pm 1,12$ \\
\hline \multirow{2}{*}{$\mathrm{M}^{+}$} & нерівномірні & 17 & $16,43 \pm 0,14^{* *}$ & $37,14 \pm 0,51$ & $63,07 \pm 1,21$ \\
\hline & рівномірні & 18 & $16,94 \pm 0,21^{* * *}$ & $41,38 \pm 0,34 * * *$ & $69,13 \pm 0,88^{* * *}$ \\
\hline
\end{tabular}

Примітка: ${ }^{*}-\mathrm{P}<0,05 ;^{* *}-\mathrm{P}<0,01 ;{ }^{* * *}-\mathrm{P}<0,001$

Аналізуючи ріст показників живої маси свиней піддослідних груп у період інтенсивного росту, можна встановити такі закономірності в динаміці іiі змін: маса піддослідних тварин усіх груп у віковий період 2-4 місяці, порівняно 3 їх живою масою на час відлучення, збільшилась у 2,4; 2,2; 2,4 і 2,4 рази відповідно.

У 4-місячному віці тварини класу «М+ $\times$ рівномірні» за живою масою переважали поросят усіх інших класів. Так, перевага над свинками класу «M- $\times$ нерівномірні» становила 8,45 кг $(\mathrm{P}<0,001)$.

3 часом різниця між дослідними групами збільшувалася й у 6-місячному віці становила 12,20 кг $(\mathrm{P}<0,001)$. Відмінності між дослідними групами «М- $\times$ рівномірні» та «M+ $\times$ нерівномірні» була незначною й у 4-місячному віці становила 2,98 кг, а у 6-місячному віці - 3,37 кг, однак різниця була не вірогідною.

Отже, результатами досліджень встановлено, що в усі вікові періоду тварини класу « $\mathrm{M}+\times$ рівномірні» мали більший приріст живої маси. Якщо прослідкувати зміни різниці живої маси між тваринами дослідних груп, то на початку досліду вона була незначною: лише 3,30-0,51 кілограма. 3 віком різниця між тваринами дослідних груп стала більш помітною: у 4-місячному віці вона становила 8,45-4,24 кг, а у 6-місячному зросла до 12,20-6,06 кілограма. Тобто, відмінності за абсолютним приростом живої маси чіткіше проявляються у віці, в якому інтенсивність росту тварин знижувалась.

Показники мінливості живої маси тварин на- ведено в таблиці 2.

Найвища мінливість живої маси у двомісячному віці встановлена для свинок великої білої породи класу «М- $\times$ нерівномірні» (коефіцієнт варіації становив 9,36\%). До 6-місячного віку мінливість живої маси у межах кожної дослідної групи зменшувалася. Зниження коефіцієнта варіації живої маси свідчить про різноманітність характеру росту в ранньому онтогенезі тварин.

Результати розрахунків середньодобового i відносного приростів свинок різних класів розподілу за вирівняністю гнізда та рівномірністю росту підтвердили наявність відмінності між досліджуваними класами за живою масою (табл. 3 i табл. 4).

Показники приростів живої маси протягом дослідного періоду були вищими у тварин класу «М+хрівномірні». Так, за середньодобовим приростом у віці 2-4 місяці вони з високою вірогідністю $(\mathrm{P}<0,001)$ переважали тварин класу «М- $\times$ нерівномірні» (перевага становила 85,86 г).

Аналізуючи вплив живої маси у двомісячному віці на динаміку середньодобового приросту встановлено, що у період 2-4 місяці свинки з більшою рівномірністю росту мали вищі на 11,90-62,05 г показники приросту, ніж свинки 3 нерівномірним ростом.

Iз віком різниця між тваринами даних класів зменшується, що свідчить про компенсаторний ріст особин із низькою живою масою у двомісячному віці; вплив рівномірності росту у підсисний період на динаміку середньодобового приросту був меншим. 
СІЛЬСЬКЕ ГОСПОДАРСТВО. ТВАРИННИЦТВО

\section{2. Показники мінливості живої маси тварин}

\begin{tabular}{|c|c|c|c|c|c|}
\hline \multirow{2}{*}{\multicolumn{2}{|c|}{ Клас розподілу за }} & \multirow[b]{3}{*}{ n, голів } & \multirow{2}{*}{\multicolumn{3}{|c|}{$\begin{array}{c}\text { Коефіцієнт варіації, \% } \\
\text { у віці, місяців }\end{array}$}} \\
\hline & & & & & \\
\hline $\begin{array}{l}\text { ирівняністю гні- } \\
\text { зда на час від- } \\
\text { лучення свино- } \\
\text { матки (в } 45 \text { діб) }\end{array}$ & $\begin{array}{l}\text { рівномірністю } \\
\text { росту }\end{array}$ & & 2 & 4 & 6 \\
\hline \multirow{2}{*}{$\mathrm{M}^{-}$} & нерівномірні & 16 & 9,36 & 6,24 & 8,05 \\
\hline & рівномірні & 17 & 5,86 & 5,52 & 5,91 \\
\hline \multirow{2}{*}{$\mathrm{M}^{+}$} & нерівномірні & 17 & 3,13 & 5,16 & 7,18 \\
\hline & рівномірні & 18 & 5,04 & 3,29 & 5,09 \\
\hline
\end{tabular}

\section{3. Динаміка середньодобових приростів відгодівельного молодняку}

\begin{tabular}{|c|c|c|c|c|c|}
\hline \multirow{2}{*}{\multicolumn{2}{|c|}{ Клас розподілу за }} & \multirow[b]{3}{*}{ n, голів } & \multicolumn{3}{|c|}{ Рівень середньодобових приростів, г } \\
\hline & & & \multicolumn{3}{|c|}{ за вікові періоди, місяців } \\
\hline $\begin{array}{c}\text { вирівняністю } \\
\text { гнізда на час } \\
\text { відлучення } \\
\text { свиноматки } \\
\text { (в } 45 \text { діб) }\end{array}$ & $\begin{array}{l}\text { рівномірністю } \\
\text { росту }\end{array}$ & & $2-4$ & $4-6$ & $2-6$ \\
\hline \multirow{2}{*}{$\mathrm{M}^{-}$} & нерівномірні & 16 & $321,43 \pm 10,25^{*}$ & $400,00 \pm 23,51$ & $360,71 \pm 11,20$ \\
\hline & рівномірні & 17 & $333,33 \pm 12,17$ & $421,67 \pm 19,88$ & $377,50 \pm 10,02$ \\
\hline \multirow{2}{*}{$\mathrm{M}^{+}$} & нерівномірні & 17 & $345,24 \pm 8,46$ & $432,14 \pm 15,18$ & $388,69 \pm 10,06$ \\
\hline & рівномірні & 18 & $407,29 \pm 6,27^{* * *}$ & $462,50 \pm 14,31$ & $434,90 \pm 8,06^{* *}$ \\
\hline
\end{tabular}

\section{4. Динаміка відносних приростів відгодівельного молодняку}

\begin{tabular}{|c|c|c|c|c|c|}
\hline \multirow{2}{*}{\multicolumn{2}{|c|}{ Клас розподілу за }} & \multirow[b]{3}{*}{ n, голів } & \multirow{2}{*}{\multicolumn{3}{|c|}{$\begin{array}{c}\text { Рівень відносних приростів, \% } \\
\text { за вікові періоди, місяців }\end{array}$}} \\
\hline & & & & & \\
\hline $\begin{array}{c}\text { живою масою } \\
\text { на час відлу- } \\
\text { чення свинома- } \\
\text { тки (в } 45 \text { діб) }\end{array}$ & $\begin{array}{l}\text { рівномірністю } \\
\text { росту }\end{array}$ & & $2-4$ & $4-6$ & $2-6$ \\
\hline \multirow{2}{*}{$\mathrm{M}^{-}$} & нерівномірні & 16 & 82,84 & 53,17 & 122,40 \\
\hline & рівномірні & 17 & 81,85 & 53,69 & 122,12 \\
\hline \multirow{2}{*}{$\mathrm{M}^{+}$} & нерівномірні & 17 & 77,22 & 51,61 & 117,11 \\
\hline & рівномірні & 18 & 83,82 & 50,13 & 121,16 \\
\hline
\end{tabular}

Відмінність між тваринами різних класів розподілу протягом дослідного періоду становила 16,79-46,21 грама.

Аналіз інтенсивності росту досліджуваних тварин проводили за розрахунком відносних приростів: даний показник вказує на напруженість росту тварин під час відгодівлі.

Результати наведено в таблиці 4.

За відносним приростом встановлено, що тварини 3 меншою живою масою у двомісячному віці мали вищий на 3,04-3,56 \% відносний приріст у 4-6-місячному віці, ніж особини 3 вищою живою масою, що свідчить про їх більш компенса- торний ріст. Аналізуючи вплив живої маси у двомісячному віці на динаміку відносних приростів встановлено, що свинки з низькою живою масою та рівномірним ростом мали максимальний показник відносного приросту за період дослідження.

Висновки: 1. Аналіз отриманих даних свідчить, що вирівняність гнізд на час відлучення та рівномірність росту мають суттєвий вплив на динаміку приростів живої маси свиней. Так, за показниками інтенсивності росту (абсолютний i середньодобовий прирости) кращими були свині 3 вирівняних гнізд на час відлучення та рівномірністю росту в підсисний період вище серед- 


\section{СІЛЬСЬКЕ ГОСПОДАРСТВО. ТВАРИННИЦТВО}

нього по стаду.

2. У 6-місячному віці свині класу «М+ $\times$ рівномірні» переважали тварин класу «М- $\times$ нерівномірні» на 12,2 кг $(\mathrm{P}<0,001)$.

3. Аналіз показників середньодобового й відносного приростів свідчить про доцільність відбору у двомісячному віці свиней із вирівняних гнізд із вищою рівномірністю росту.

4. Протягом дослідного періоду свинки даної

\section{БІБЛІОГРАФІЯ}

1. Коваленко В. П. Сучасні методи прискорення селекційного прогресу в птахівництві / В. П. Коваленко // Птахівництво: Міжвід. темат. наук. зб. (Матеріали VII Укр. конф. по птахівництву 3 міжнарод. уч., 18-22 вересня, 2006 р., м. Алушта) / ІП УААН. - Харків, 2006. Вип. 58. - С. 98-103.

2. Крамаренко С. С. Метод использования энтропийно-информационного анализа для количественных признаков / С. С. Крамаренко // Известия Самарского научного центра Российской групи переважали за середньодобовим приростом своїх ровесників класів «М+ $\times$ нерівномірні», «М- $\times$ рівномірні», «М- $\times$ нерівномірні» на 46,21, 57,4 і 74,19 г відповідно.

5. Отримані дані доцільно використовувати на племінних заводах, племрепродукторах і товарних фермах для оптимальної комплектації груп свиней і підвищення енергіï їх росту на вирощуванні та відгодівлі.

академии наук. - 2005. - Т. 7, №1. - С. 242-247.

3. Ломако Д. В. Вивчення ознак відтворювальної здатності свиноматок при чистопородному розведенні. - Дис. ... канд. с.-г. наук. - Полтава, 2000. $-155 \mathrm{c}$.

4. Пелих В. Г. Селекційні методи підвищення продуктивності свиней. / В. Г. Пелих. - Херсон: Айлант, 2002. - 264 с.

5. Плохинский $Н$. А. Математические методы в биологии / Н. А. Плохинский. - М. : Изд-во Московского ун-та, 1978. - 265 с. 